\title{
The Nation and the Nation State in the Mirror of Czech and Polish Sociological Journals in the Interwar Era ${ }^{1}$ \\ Dušan JANÁK, jr.
}

\begin{abstract}
The following text offers a comparison of Czech and Polish sociological journals of the interwar era related to the problems of the nation and the nation state. A combination of quantitative and qualitative content analysis is used for comparing formal characteristics (institutionalization, periodicity, types, number and size of articles), and thematic structure. Czech sociology had a closer relationship to nation-state politics, which was shown at the level of institutional (in)stability of the journals, at the level of personal involvement of journals' leading figures in politics as well as at the level of discourse, where different relevance and content were attached to the subject of nation in each country. Regarding this issue Czech sociology (represented in journals in the 1930s) was closer to public sociology while the Polish discourse to policy sociology.
\end{abstract}

\section{Keywords}

Central Europe, Czech sociology, Polish sociology, the nation, nation state, content analysis, sociological journal

\section{Introduction}

The purpose of the following text is to present a part of the results of a content analysis of Czech and Polish sociological journals between the world wars focused on the problems of the nation and the nation state. The Czech journals Sociologická revue [Sociological review], Sociální problémy [Social problems] and the Polish journals Przegląd Socjologiczny [Sociological review] and Roczniki Socjologii Wsi [Yearbook of rural sociology] were examined. These periodicals were not the only platform for the exchange of opinion within a specific academic community, but in the 1930s, they undoubtedly provided the most representative one. The professional sociological journals in both countries represented the final step in institutionalizing a discipline that coincided with the founding of both the

1 This research was supported by the Czech Science Foundation (Grant No. 15-04099Y: Sociology in Central Europe before World War II in Comparative Perspective). 
Czechoslovak and Polish states. The analysis focused on the era's sociological discourse at a highly developed stage. The first and most important sociology periodicals appeared in the same year (1930) in both the Czech lands and in Poland; this is more or less a coincidence, which provides a convenient framework for their mutual comparison. ${ }^{2}$

The main idea and the broader question underlying our investigation arises from the following consideration: The institutionalization of sociology and its establishing as an academic discipline coincided in Czechoslovakia and Poland with the establishing of these two countries as national states. We may ask about nature of the relation of the discipline towards the nation state structures? Were the nation-related issues topical among interwar sociologists? What kind of sensitivity did they have towards the problem which was essential for the new states in which they were newly institutionalized?

Our comparison in this paper focuses on the problems of nation represented in the journals in two ways. The first focuses on the institutional level, that is, on the duration of the journals and their leading figures' involvement in the political life of the newly established nation states in which sociology was newly established as an academic discipline as late as in the interwar era. The second approach focuses on the discursive level in the interwar era, and is based on the content analysis in sensu stricto. Analysis of these two aspects of the journals should contribute to a better understanding of both sociological traditions as well as to the broader problem of the relationship between sociology and the nation state.

\section{Method}

In our research, we have focused on purely sociological journals, although sociological texts can of course be found in reviews in other disciplines or in general educational periodicals, both before the advent of the professional journals, and after their appearance as well. However, it would be rather difficult to methodologically distinguish between them (i.e. to separate sociology from non-sociology); the task of doing so would be difficult to carry out (it would involve far too much text to process), and would probably lack significant informational value. ${ }^{3}$

For the purposes of our research, the method of content analysis was chosen, which focuses on characteristics that are easily measurable using formalized approaches (number

2 The certain duality of Czech sociology, which from 1918 to March 1939 developed along with Slovak sociology within the common state, presents a methodological problem. An ambivalent tension between the Czechs and the Slovaks on the one hand, and the inseparable Czechoslovak national identities on the other, was also discernible in sociology, in which we can observe both unifying and separatist tendencies. An integrated Czechoslovak sociology turned out to be a successful project only to a limited extent, like the vision of Czechoslovak national identity, with only some sociologists having contributed to its construction, and in varying ways. Our approach therefore considers the differences between the two nations rather than the state border. There were sociologists in Slovakia, but sociology as an institutionally developed field of study was not present. Czech professors taught at the university in Bratislava until 1938, and a journal was founded there as late as after the war, when the Slovak sociological generation emerged in the late 1930s. Still, the relation to Slovak sociology or Slovakia in general needs to be appropriately considered when interpreting the results.

3 In Czechoslovakia, a number of sociologically oriented texts can be found in the magazines Česká mysl, Naše doba, Parlament (which for part of one volume 1928/1929 actually contained a sociology section) and Ruch filosofický. In Poland, for example, see Ruch Prawniczy, Ekonomiczny i Socjologiczny (in which only fifteen sociological articles were published, mainly reviews of sociological publications), Droga, Przegląd Współczesny Nauka Polska, Chowanna, Kultura i Wychowanie and Wiedza i Życie. 
of articles, their size, type of text, authorship, author's origin, etc.), as well as analysis of the articles' thematic content. To capture this information, we used a combination of closed and open coding. The text was first put into one of five basic categories: social reality, sociology, sociological theory and epistemology, method of empirical research and "other". Each article was given a code consisting of a maximum of eight words or word combinations descriptive of its content. Through further analysis and recoding, we arrived at some more general terms covering certain broader topic areas, which we call thematic centres. ${ }^{4}$ A more general methodological problem follows from the dual role of journals in our research: they are an object of study and at the same time the source of information for the study of differences between Polish and Czech sociology. They can be used as a source providing that they represent what is characteristic of the whole of sociology in both countries to a similar degree. We assume that this is the case in our study. The following table shows that the journals were typically founded during the final phase of the institutionalization of sociology, which followed basically the same trajectory both in Poland and in Czechoslovakia.

4 The reliability of dichotomous and little-varying variables were tested by the Holsti coefficient with the satisfactory result of at least 0.7 . With the variable of a thematic type, using closed coding to describe the topic of the article; Scott's $\pi$ coefficient was used, resulting in a value of at least 0.78 . With open coding, quantifying procedures cannot be used; what can be used is a mutual discussion of semantic similarities in the codes used. By classifying articles according to codes of higher generality, a formalized test of reliability can again be set up, with which the Scott $\pi$ value was about 0.86 . An operational definition of key variables from the coding book is given in Methodological Appendix 1. On the issues of testing reliability, see BELL, Philip: Content Analysis of Visual Images, in: Handbook of visual analysis, LEEUWEN, Theo van - JEWITT, Carey (eds.), London - Thousand Oaks - New Delhi 2001, 10-34; KRIPPENDORF, Klaus: Testing the Reliability of Content analyzing Data: What is Involved and Why, in: The Content Analysis Reader, KRIPPENDORF, Klaus - BOCK, Mary Angela (eds.), Los Angeles - London - New Delhi - Singapore 2009, 350-357; RIFFE, Daniel - LACY, Stephen - FICO, Frederick G.: Analyzing Media Messages. Using Quantitative Content Analyzes in Research, Mahwah, New Jersey - London 2005; SCHERER, Helmut: Úvod do obsahové analýzy, in: Analýza obsahu mediálních sdělení, SCHULZ, Winfried - HAGEN, Lutz SCHERER, Helmut - REIFOVÁ, Irena - KONČELÍK, Jakub (eds.), Prague 1998, 29-53; SCOTT, William A.: Scott's $\pi$ (Pi): Reliability for Nominal Scale Coding, in: The Content Analysis Reader, KRIPPENDORF, Klaus - BOCK, Mary Angela (eds.), Los Angeles - London - New Delhi - Singapore 2009, 347-349. 
Table 1. Landmarks in the institutional development of Czech and Polish interwar sociology

\begin{tabular}{|c|c|c|}
\hline $\begin{array}{l}\text { Type of } \\
\text { institution }\end{array}$ & Czechoslovakia & Poland \\
\hline $\begin{array}{l}\text { University } \\
\text { courses }\end{array}$ & $\begin{array}{l}1919 \text { Charles University, Prague } \\
1922 \text { Masaryk University, Brno } \\
1924 \text { Comenius University, } \\
\text { Bratislava }\end{array}$ & $\begin{array}{l}1919 \text { Uniwersytet Warszawski } \\
1920 \text { Uniwersytet Poznański } \\
1922 \text { Wolna Wszechnica, Polska, Warszava } \\
1927 \text { Uniwersytet Jagielloński, Krakow } \\
1936 \text { Szkoła Główna Gospodarstwa } \\
\text { Wiejskiego, Warszava* }\end{array}$ \\
\hline $\begin{array}{l}\text { Research } \\
\text { institutes }\end{array}$ & $\begin{array}{l}1919 \text { State Statistical Institute } \\
1924 \text { Sociological Commission of } \\
\text { the Czechoslovak Academy } \\
\text { of Agriculture }\end{array}$ & $\begin{array}{l}1918 \text { Główny Urząd Statystyczny } \\
1920 \text { Instytut Gospodarstwa } \\
\text { Społecznego } \\
1931 \text { Instytut Spraw Społecznych } \\
1936 \text { Państwowy Instytut Kultury Wsi }\end{array}$ \\
\hline $\begin{array}{l}\text { Scholarly } \\
\text { societies }\end{array}$ & $\begin{array}{l}1925 \text { Masaryk Sociological Society } \\
1937 \text { Society for Social Studies }\end{array}$ & 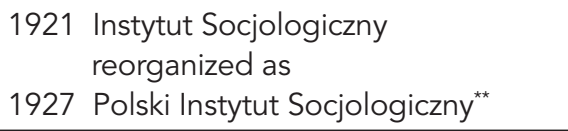 \\
\hline $\begin{array}{l}\text { Specialist } \\
\text { journals }\end{array}$ & $\begin{array}{l}1930 \text { Sociologická revue } \\
1931 \text { Sociální problémy }\end{array}$ & $\begin{array}{l}1930 \text { Przegląd Socjologiczny } \\
1936 \text { Roczniki Socjologii Wsi }\end{array}$ \\
\hline
\end{tabular}

* The dates of the founding of the departments come from N. Kraśko (1996). Sociology as a separate field of study was realized in 1930; until then, it had been taught in different departments e.g. law, pedagogy and the like. ** Polski Instytut Socjologiczny is referred to as a research institute in the literature (CHAŁASIŃSKI, Józef: Trzydzieści lat socjologii polskiej, in: Przegląd Socjologiczny, vol. X, 1948, 1-57), but its character was more of a scientific association.

Source: Authors

We cannot quantify the degree to which the journal mirrors the structure of the discourse by analogy to a random sample from the population. The principal problem is that the boundary between what still belongs to and what is already outside the scope of sociology is unclear and changeable over time and within different territories. When examining the origins of sociology, it is better to depart from the self-definition of the science (sociology is what considers itself sociology) rather than the a priori normative model of a science. ${ }^{5}$ Given the similarities in the institutional development that and also because all the important sociologists contributed to the journals, we assume that they represent a very important publication (that is discursive) platform for sociology. In this sense we can consider the journals as a sample of sociological discourse and we must be careful when it comes to generalizing about the similarities and differences found between the examined journals.

5 KLOBUCKÝ, Robert: Hlasistické hnutie: národ a sociológia. Začiatky sociologického myslenia na Slovensku, Bratislava 2006, 20-36. 


\section{Results}

\section{The Journals" Founding, Their Editors and "Dangerous Involvement" in Politics}

The most extensive of all the periodicals we studied was the Sociologická revue (henceforth also SR). In the inter-war period, Sociologická revue was the main Czech journal in the field. It was first published in 1930 in Brno, interrupted by the war from 1941 to 1945, and came out quite regularly until 1949, when its publishing became impossible for political reasons. The Sociologická revue was the official body of the Masaryk Sociological Society, which likely financed it in part, although a significant part came from private sources, among others from the income of its chief editor and founder of the sociological seminar in Brno, I.A. Bláha, who headed the journal for the entire period of its existence (before the Second World War together with E. Chalupný, J.L. Fischer and partially with Slovak A. Štefánek). The journal was published as a quarterly, but sometimes more than one volume was issued at the same time.

The journal Sociální problémy (henceforth also SP) was first published in Prague in 1931 and continued, with some interruptions, until 1947. After February 1948, it was no longer permitted to be published for political reasons. The journal came out for a total of seven years, in the final two under the title Sociologie a sociální problémy. For its entire run, the core editorial team consisted of J. Král, Z. Ullrich and O. Machotka. To them, we can add a stable group of collaborators from related fields (statistician and demographer A. Boháč, political sociologist J. Mertl, economist V. Vybral, etc.). The journal was published through the publishing house Orbis, and was probably in financial straits for the entire time of its existence, which was reflected in its uneven periodicity. At first, it came out as a bimonthly, later a quarterly, but sometimes issues were joined together as well. It was started by the Prague sociologists more or less as a rival to Brno's Sociologická revue. ${ }^{6}$ The Prague and Brno journals represented two diverging schools of sociology. Analysis of their mutual disagreements, discussions and polemics, and declarative and real differences, would no doubt merit attention, but is outside the scope of this text. ${ }^{7}$

Przegląd Socjologiczny (henceforth also PS) was first published in Poznan in 1930, but its second edition did not appear until 1934. From 1935 onward, Przegląd usually came out twice a year (every issue consisted of two volumes). In 1935, when F. Znaniecki was replaced by J. Chalasiński as editor in chief, it moved its offices to Warsaw and the journal was given the subtitle A Quarterly of the Polish Institute of Sociology. Among Znaniecki and Chalasiński's most important colleagues were A. Hertz, W. Okiński, S. Rychliński and T. Szczurkiewicz. The journal's publication was interrupted in mid-1938, renewed in 1946 and

6 VORÁČEK, Emil: Emanuel Chalupný, problémy rozvoje sociologie v Československu 20. let a vznik Masarykovy sociologické společnosti, in: Emanuel Chalupný, česká kultura, česká sociologie a Tábor, ZUMR, Josef (ed.), Prague 1999, 107-132; PAVLINCOVÁ, Helena: Chalupný a Brno, in: Emanuel Chalupný, česká kultura, česká sociologie a Tábor, ZUMR, Josef (ed.), Prague 1999, 23-31.

7 For such an analysis, see NEŠPOR, Zdeněk R.: Před 3/4 stoletím... Kvantifikovaný esej o časopisecké produkci české sociologie před nástupem marxismu a dnes, in: Sociologický časopis, 43, 2007, 2, 397-422; JANÁK, Dušan: Brněnská versus pražská sociologická škola: mýtus a skutečnost, in: Sociologický časopis, 49, 2013, 3, 577-602. 
banned again in 1949 with the political changes in Poland, which, as in Czechoslovakia, included a ban on sociology. The Przegląd was renewed in 1957 and with some changes in periodicity is still being published today.

The first issues of Rocznik socjologii wsi (henceforth also RSW) first saw the light of day in 1936 at the Institute for Rural Sociology of the Central School of Rural Economy. Besides members of the institute, W. Bronikowski was one of its editors. The last issue of the interwar period came out in 1938, a year after the death of W. Grabski. In the post-war years, the title was taken up again in 1963, when the journal Roczniki socjologii wsi. Studia i materiały was established at the Institute of Sociology and Philosophy, Polish Academy of Sciences. The new periodical had a somewhat different profile, its editors wishing mainly to present the results of narrowly focused empirical research (-1963: 5-6). Only the title remained the same. In the 1980s, its publication was moved back to the Central School of Rural Economy. Since 2006, the journal has returned more to the legacy of W. Grabski, and members from various areas of Polish academia serve on the board of editors.

The first difference between Czech and Polish journals is that the Czech journals were not renewed during the communist regime, although considering the way they were started, we might have expected them to continue. This divergence was clearly due to the differing political situations in the two countries during the 1950s, which caused radical discontinuity in the development of Czech sociology. It is likely that the shadow of the abrupt departure of the communist regime from the interwar political system also reached sociology, which was connected with the political elites of the First Republic more closely than in Polish sociology, and after 1948, it was abolished as "bourgeois pseudo-science", including its institutional pillars. If we run through the names mentioned above in relation to the individual editorial circles, we see that it was Czech sociologists who were more deeply involved in political life.

Bláha founded a political party in 1925 and unsuccessfully stood as a candidate for the national assembly. ${ }^{8}$ Chalupný was a member of the Czech People's Party even before the First World War, where he worked in the party's press bodies and from 1903-1904 he was a member of its executive committee for a short time. Between 1906 and 1911, he actively engaged in Czech social life. ${ }^{9}$ Fischer was publicly committed in the 1930s, particularly to the anti-Nazi movement, he took part in the support of Republican Spain and later organized help for emigrants from Nazi Germany, he edited a leading left-wing magazine Index and for a short time, he was a member of the Communist Party. ${ }^{10}$ Machotka was politically active in the National Socialist Party, he joined resistance during the Second World War, in April and May 1945, he was a Vice Chair of the Czech National Council, between 1945 and 1948, a Vice Chair of the Czech Provincial National Committee and one of the main ideologists of the National Socialist Party and in 1947, a member of the Party presidium. He was among the first victims of the communist regime following February 1948; however, in March 1948, he managed to emigrate to the USA, where he continued

8 SEDLÁK, Jiří: Inocenc Arnošt Bláha, Brno 1995, 165-167.

9 NEŠPOR, Zdeněk R.: Chalupný Emanuel, in: Slovník českých sociologů, NEŠPOR, Zdeněk R. a kol., Prague 2013, 126.

10 PETRUSEK, Miroslav: Fischer Josef Ludvík, in: Slovník českých sociologů, NEŠPOR, Zdeněk R. a kol., Prague $2013,72$. 
his academic career. ${ }^{11}$ A Slovak Štefánek entered into active politics following the formation of Czechoslovakia as a member of the "interim Slovak government" transformed into the ministry with full authority for the administration of Slovakia, where he was in charge of the department of education. In 1929, he was a minister of education and national awarenessraising. From 1925 to 1935, he was a deputy and from 1935 to 1938 a senator for the Agrarian Party. ${ }^{12}$

The only politically active figure among social scientists in Poland was Grabski, though indeed at the very top level. Grabski had already been politically active before the First World War as the deputy of the State Duma of the Russian Empire (1906-1912), he participated as the Polish delegate for peace negotiations in Paris at the end of the First World War, in the inter-war period he was a minister of agriculture (1919) and he twice held the office of Prime Minister (1920, 1923-1925). ${ }^{13}$ Of the other Polish members of editorial staffs, only A. Hertz can be mentioned, whose political involvement was limited to the fight for Polish independence before the formation of the Second Polish Republic; W. Bronikowski engaged in anti-Nazi resistance at the beginning of the Second World War, which consequently led to his death at Auschwitz. ${ }^{14}$

The positions of chief editors, too, probably played a partial role. While both Polish periodicals had already gone through changes in their editorship during the interwar period, the Czech journals were perhaps too strongly dependent on their leading personalities, and so to renew the journals without them was almost unthinkable. Our study of the different histories of the sociological periodicals in the two countries shows that the promising Czech sociology ended up defeated and with its continuity broken, while despite their more tentative beginnings, the Polish journals were eventually able to resume publishing in something resembling their original spirit. Regarding the editors we could mention that editors in chief of the first sociological journals in both countries were recognized abroad as leading sociologist in this European region. We can see Bláha from Czechoslovakia and Znaniecki from Poland in E. Eubank's list of interviewed sociologist during his sociological trip to Europe in $1934 .{ }^{15}$

\section{Description of the Research Sample for the Content Analysis}

A total of 2,726 texts were analyzed, 2,259 in Czech journals and 467 in Polish journals. When counted in terms of standard pages, the seemingly enormous gap in the size of output between Czech and Polish journals shrinks from 5:1 to 2:1 in favor of the Czech periodicals. The proportion of individual yearly output was greatly affected by the sporadic

11 NEŠPOR, Zdeněk R.: Machotka Otakar, in: Slovník českých sociologů, NEŠPOR, Zdeněk R. a kol., Prague 2013, 223.

12 JANÁK, Dušan: Štefánek Anton, in: in: Slovník českých sociologů, NEŠPOR, Zdeněk R. a kol., Prague 2013, 398.

13 WINCŁAWSKI, Włodzimierz: Słownik biograficzny socjologii polskiej, Toruń 2001, 202; MORAWSKI, Wojciech: Władysław Grabski, polityk, mąź stanu, reformator, Warszawa 2004.

14 WINCŁAWSKI, 53, 227.

15 KÄSLER, Dirk: Soziologische Abenteuer: Earle Edward Eubank besucht eurupäische Soziologen im Sommer 1934, Opladen 1985, 93-96, 110-114. 
periodicity of some of the journals, whether for financial reasons (esp. SP) or personnel reasons (for example PS, when Znaniecki left for a posting in the USA); and of course the Second World War put an end to everything. The following graphs present concise information on the size of the output by Czech and Polish journals.

Graph 1a. Number of standard pages in yearly volumes in Czech
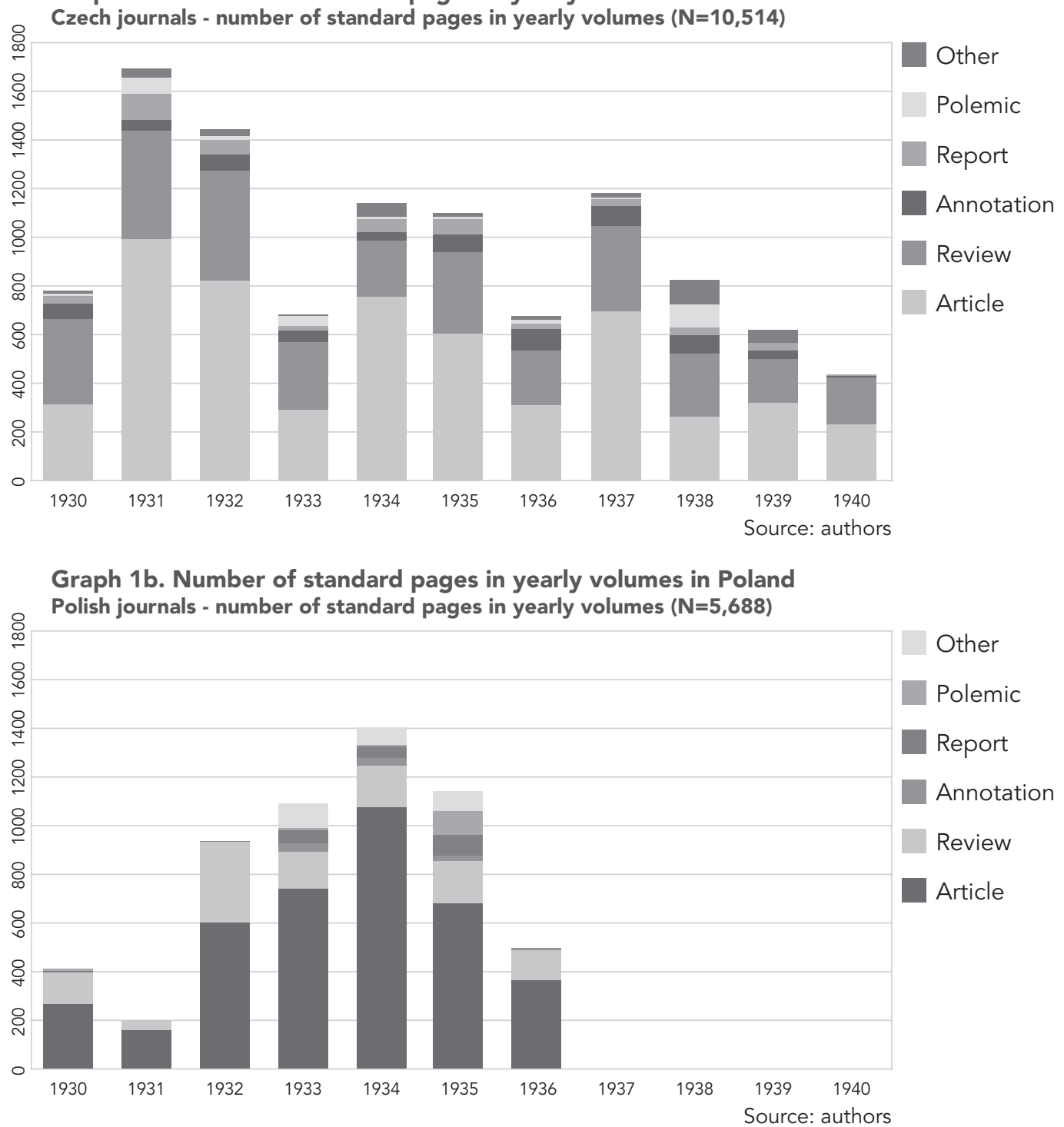

The high point of the Czech journals' productivity came in 1931 and 1932; meanwhile, at that time the chief editor and the deputy of the only existing Polish journal were out of the country. The Polish journals had their heyday in 1937, when the size of their output was similar to that of the Czechs. The marked difference in the total output is mainly a reflection 
of the steep decline on the Polish side. On the other hand, the output by the Czechs, given the size of the country, was rather extensive.

If we consider the distribution of types of text according to number of standard pages, the journals in both countries were dominated by the article form, though with different proportions of the overall number. The Czech sociological community was more "busy", such as covering news of events in the academic community, reviews of the literature of the day and anniversary portraits, and a good number of hotly contested polemics. Both the professional journals were founded by rather antagonistically minded groups of sociologists: critical reviews of the "competing" sociological product were common, and tended to boil over into polemics that sometimes resembled monologues, in which one journal would print reviews of the articles that appeared in the rival journal. The tension and polemics were reflected in separate publications on the history of Czech sociology, which pointed to deeper differences between the two sociological schools ${ }^{16}$ and were also manifested by delimitation of the authors' circles.

The Czech Sociologická revue had special standing among the inter-war journals in both countries, mainly for its prodigious output, ${ }^{17}$ which was for the most part accompanied by meticulous reviews, thanks to which readers were quite well informed about worldwide sociology, including developments in Central and Eastern Europe. The review published a large number of authors (212 identifiable), including foreign authors, who contributed roughly 30 percent of the articles. It was the only journal in the inter-war era not to miss an issue.

In order to adequately interpret the volume of Czech and Polish production of sociological journals, represented by the two graphs above, it is useful to provide additional summary information about selected indicators on the cultural production of the two countries as the whole. Of the available indicators, we have chosen the number of university students and the overall number of published book titles in the year both journals started to appear (see Table 2).

Table 2. Comparison of the cultural production in Poland and Czechoslovakia in selected areas

\begin{tabular}{|c|c|c|c|}
\hline Country & $\begin{array}{c}\text { Population } \\
\text { in 1930 }\end{array}$ & $\begin{array}{c}\text { Number of university } \\
\text { students }\end{array}$ & $\begin{array}{c}\text { Number of published } \\
\text { books in 1930 }\end{array}$ \\
\hline Poland & $32,107,000$ & $\begin{array}{c}48,200 \\
\text { (academic year 1930/31) }\end{array}$ & 5,271 \\
\hline Czechoslovakia & $\begin{array}{c}14,004,033 \text { (of that } \\
\text { Czech lands 10,674,240, } \\
\text { Slovakia 3,329,793) }\end{array}$ & $\begin{array}{c}34,100 \\
\text { (academic year 1931/32) }\end{array}$ & $\begin{array}{c}5,878 \\
\text { (of that 4,859 in } \\
\text { Czech or Slovak) }\end{array}$ \\
\hline
\end{tabular}

Source: Processed according to KILIAS, Jaroslaw: An older Brother: Polish and Czechoslovak Sociology in the 1960s, 2015 (unprinted paper), using the data from the publications (KUBICZEK, Franciszek: Historia Polski v liczbach. Zeszyt 4 - oświata, nauka, kultura, Warszawa 1992, 223; KUKLO, Cezary - ŁUKASIEWICZ, Juliusz LESZCZYŃSKA, Cecylia: Historia Polski v lizcbach / History of Poland in Numbers, Warszawa 2014, 53; Statistická ročenka republiky Československé, Prague 1934, 229-230) and the data from Český statistický úřad (www.csu.cz).

16 NEŠPOR, 2007; JANÁK, Dušan: Brněnská versus pražská sociologická škola: mýtus a skutečnost, in: Sociologický časopis, 49, 2013, 3, 577-602.

17 Around 7,000 standard pages, or 40 percent of the total production of all journals in both countries. 
If we relate these data to the size of the population of the two countries, we will see that the relative volume of cultural production was larger in Czechoslovakia. Although there have been no detailed statistics published so far on the number of students of sociology in the inter-war period for Poland, the preliminary findings indicate that on a relative and probably on an absolute scale as well, the numbers were smaller than in Czechoslovakia and the data on the overall numbers of students can largely be related to sociology as well. ${ }^{18}$ The larger volume of sociological production of the Czech journals as compared to that of the Polish journals has its parallels in both the overall number of university students and the number of book titles published. The data not only reflect the attention given to, but also the amount of financial means directly or indirectly invested in education and books. Using the idea of J. Kilias that in the case of the institutionalization of sociology we should also consider its depth, we can conclude that the institutionalization of sociology was less deep in Poland than in Czechoslovakia. The deeper foundation of institutionalization of Czech sociology was not (only) due to the relationship of its representatives with politics, but also to the generally larger cultural productivity of the country.

\section{Nation as the Theme of the Journals}

While closed coding tried to divide articles into a few rough and pre-determined categories, the aim of open coding was to find the dominant theme inductively. During the qualitative thematic analysis of the subset of articles and treatises, various major thematic areas crystallized, of varying size, about 30 of them in the Czech journals and 25 in the Polish, according to the more general codes assigned to them. For greater clarity, these thematic centres were ranked according to the number of texts they include into five categories of size. ${ }^{19}$ The boundaries were set with a view to the large differences in proportion. Where the classified centers did not have clear lines between them and began to form a continuum, we used fractile logic calculated according to the value of the largest centre of the continuous field to maintain the relative proportions between Czech and Polish periodicals. The position of the thematic centre related to the nation is highlighted in the table 3 .

18 Based on personal consultation with J. Kilias.

19 We regard the use of quantitative logic in the analysis of qualitative data as legitimate because it is a relatively common and recommended approach (for example SILVERMAN, David: Doing Qualitative Research. A Practical Handbook, London - Thousand Oaks - New Delhi 2000, 184-185), and also because we are interested in finding the most frequent topics. In the language of quantitative analysis, we did not work with a selected sample, but instead did an exhaustive study. We did not include centres with less than four articles, because the term loses its meaning. 
Table 3. Distribution of thematic centres in Czech and Polish journals

\begin{tabular}{|c|l|l|}
\hline level & \multicolumn{1}{|c|}{ Czech journals } & \multicolumn{1}{|c|}{ Polish journals } \\
\hline 1. & Sociology domestic or foreign (130) & Sociology domestic or foreign (62) \\
\hline 2. & $\begin{array}{l}\text { economy (39); economic depression (37); } \\
\text { the nation (33) }\end{array}$ & Rural society (31) \\
\hline 3. & $\begin{array}{l}\text { Politics and democracy (29); rural } \\
\text { society (27); science and knowledge (26); } \\
\text { labor-workers-unemployment (24); } \\
\text { family, children (24); }\end{array}$ & $\begin{array}{l}\text { schools-education (18); } \\
\text { labor-unemployment (14); art and culture } \\
(14) ; \text { politics and democracy (13) }\end{array}$ \\
\hline 4. & $\begin{array}{l}\text { law (19); art and culture (19); education } \\
\text { (17); Marxism and socialism (16); religion } \\
\text { (14); social planning (12); morality-norms } \\
\text { (12); the people (12); the military (11); } \\
\text { youth (11) }\end{array}$ & $\begin{array}{l}\text { science and knowledge (10); the individual } \\
\text { and society (10); social planning (9); family } \\
\text { and children (9); morality-norms (8); } \\
\text { the state (8); migration (8); religion (7); } \\
\text { youth (7); the nation (7); the people (7) }\end{array}$ \\
\hline 5. & $\begin{array}{l}\text { media (10); German fascism (8); } \\
\text { population (8); women's issues (gender) } \\
\text { (7); intelligentsia (6); social structure (4); } \\
\text { migration (6); technology (5); the state (5); } \\
\text { social development (4); revolution (4); } \\
\text { the individual and society (4); social } \\
\text { structure (4) }\end{array}$ & $\begin{array}{l}\text { conflict (6); economic depression (6); } \\
\text { the economy (5); German fascism (5); } \\
\text { law (4) urban environment (4); } \\
\text { technology (4); war and the military (4); }\end{array}$ \\
\hline
\end{tabular}

Whereas the topic of nation was one of the most frequent topics in Czech sociology, it was relatively marginal in Poland. J. Kurczewska observes on this stage in the development of Polish sociology that other social theory and practical problems were important at the time, for example, the problems of the organization of sociology as an academic discipline, the sociology of education, the sociology of culture, or socio-economic structures. Especially in the late 1920s, she writes, there was a state of "saturation with the problem of the nation". The symptoms of that saturation were found in two reactions, says Kurczewska: the first was a concentration on the "pure" theory of culture and social science and an emphasis on the "Europeanness" of Polish sociology, i.e. on topics of an abstract and theoretical nature. The second was a concentration on politics and pedagogy, research on the working class and peasant culture; i.e. topics of a concrete and empirical nature. ${ }^{20}$ If we look at Table 3, which summarizes the thematic centres according to size, we see that our analysis based on specific material essentially confirms the above statement. In accordance with our findings, we would place rural society ahead of all the other topics; but we do not find in the journals much evidence of any attempt at Europeanness by Polish sociology, as their circle of authors was clearly tied to the Polish cultural environment.

As for national issues, especially in the 1930s, we can observe acceptance of the national idea in the right-wing, nationalist environment. The Polish sociological community, which 
J. Kurczewska describes as "liberal or left-wing", ${ }^{21}$ did not accept this ideology of the nation and stood in opposition to both of the mutually antagonistic political camps: the national democracy of Roman Dmowski, and the so-called "Sanitation" of Józef Pilsudski. J. Chalasiński writes that the issue of the nation was in vogue in other academic fields, especially in history, but sociology and history were then developing without interaction, which according to Chalasiński, was due to the political orientation of many historians. ${ }^{22}$ Given the different political context, the theme of the nation resonated much more in the Czech lands. ${ }^{23}$ After 1918, the people of Czechoslovakia were faced with the problem of creating a unified Czechoslovak national identity (for example, in the census people could only claim Czechoslovak nationality, and not Czech or Slovak). This situation was essentially different from that in Poland. The pragmatic political reasons were simple: to gain predominance over the ethnic German minority in the Czech lands, and in Slovakia over the Hungarian minority. The methods of constructing and legitimizing Czechoslovak national identity were by no means simple, not to mention the structure of Czech-Slovak relations. This was probably also the source of sensitivity among Czech sociologists to the topic of the nation. However a large portion of the population in Poland was also of nonPolish ethnicity, and the sources of the sensitivity to the topic in the Czech lands while, on the other hand, the reasons of the declining sensitivity to the same within the Polish sociological discourse as reflected in the journals ${ }^{24}$, should also be looked for in the relation of the academic sociological to the public political discourse.

The socio-political situation also reflects the main lines of dispute within this topical centre, running along three thematic axes. The first was connected to the topic of the national struggle, which emphasized the importance of different sociologists for the national struggle, and the connection between the development of sociology in a given territory and the political issue of the nation. ${ }^{25}$ The second major axis was the theme of the nation under threat from National Socialism in Germany, which was magnified in 1938 with the Munich Accords. ${ }^{26}$ The third relatively independent axis consists of the problematic relationship between Czechs and Slovaks, and the related question of other ethnic minorities. ${ }^{27}$

All three cases evidently involved political subtopics. It seems that the closer connection with politics as compared with the Polish discourse, did not only apply to the institutional, but also to the discursive levels of the Czech sociological journals. If we take into account indirect indicators of the greater political engagement among Czech authors derived from

21 lbidem, 12.

22 CHAŁASIŃSKI, Józef: Trzydzieści lat socjologii polskiej, in: Przegląd Socjologiczny, vol. X, $1948,39$.

23 cf. KILIAS, Jaroslaw: Narodowość jako problem naukowy. Naród w socjologii czeskiej okresu międzywojennego, Warszawa 2000.

24 For more details on the general overview of nation-related problems in Polish sociology and the reflection of the diminishing relevance of this topic see (KURCZEWSKA, Joanna: Dusza społeczeństwa. Naród w polskiej myśli socjologicznej, Warszawa 2002, 5-30).

25 For example KOSIĆ, Mirko: Stav sociologického studia u Jihoslovanů, in: Sociologická revue, 2, 1931, 3, 334-339; ŠAPOVAL, Mykyta: Soudobá ukrajinská sociologická myšlenka a práce, in: Sociologická revue, 2, 1931, 2, 195-202; ŠAPOVAL, Mykyta: Soudobá ukrajinská sociologická myšlenka a práce, in: Sociologická revue, 2, $1931,4,49-55$.

26 e.g. FISCHER, Josef, L.: "Na křižovatce", in: Sociologická revue, 9, 1938, (1-2), 260-264.

27 ŠTEFÁNEK, Anton: Príspevok ku československému bilinguizmu, in: Sociologická revue, 2, 1931, 1, 20-29; ŠTEFÁNEK, Anton: Novoslováci, in: Sociologická revue, 4, 1935, 3-4, 272-277. 
the political biographies of members of the aforementioned editorial circles, we might suppose that the absence of the topic in the Polish journals was due to its evident political character. Analysis of further resources (primarily books) would be required, however, to confirm and generalize this finding. J. Chałasiński, who succeeded Znaniecki in the management of PS, devoted attention to ethnic conflicts in Silesia at least at the level of empirical research. ${ }^{28}$ The analysis of the journals will not reveal to us whether the topic was rather rare or, to the contrary, more broadly discussed in other areas of sociological discourse. From the perspective of the content analysis of the journals, we can say that although both Czechoslovakia and Poland were newly formed states, in one of them the theme of nation was sociologically more relevant than in the other one. The level of closeness of the relationship between sociology and politics and, on the other hand, the different course of building of the state can be considered as relevant circumstances explaining the difference. In Poland, the restoration of the lost administrative unity on the basis of cultural unity (Polish national identity) was involved, while Czechoslovakia sought the building of a new political identity in terms of culture (Czechoslovakism) as well as administration in the context of multi-level ethnic / national minority related conflicts and tensions. ${ }^{29}$

To gain a broader perspective we can use the typology of sociological work offered by M. Burawoy within a discussion of what is known as public sociology, which subsequently evolved into a worldwide debate. ${ }^{30}$ The division of sociological labour according to Burawoy is shared by professional, critical, public and political/commission (policy) branches of sociology. Each has its specific procedures, audiences and goals. Recipients and users of the former two are sociologists themselves, while professional sociology remains a substantive core of the field, since the focus of public and policy sociology is outside the field. The proportions of individual types of sociological work vary in time and space, sometimes hypertrophy or atrophy of some type occurs. Given the identified differences within the nation-related topics we could say that the ratio between public and policy sociology was different in the Polish and Czech sociological discourses in the 1930s.

While the Polish discourse saw the shift of focus from 'public' to 'policy' sociology, which can be characterized by notions such as europeanization, ${ }^{31}$ westernization ${ }^{32}$ or transformation of normativity, the Czech discourse retained its stronger relation to public sociology even after sociology was established as an academic discipline. The key factor here seems to be political engagement of the important figures in the science. Their influence on the discourse was not only direct through author texts and researches, but

28 CHAŁASIŃSKI, Józef: Antagonizm polsko-niemiecki w fabrycznej osadzie "Kopalnia" na Górnym Śląsku, in: Przegląd Socjologiczny, 3, 1935, 1-2, 146-278.

29 The basic axes of ethnic / national minority based tensions were formed by the relationships between Czechs - Slovaks - Czechoslovaks, Czechs - Germans, Slovaks - Hungarians.

30 cf BURAWOY, Michael et al.: Public Sociologies: A Symposium from Boston College, in: Social Problems, 51, 2004, 1, 103-130; BURAWOY, Michael: 2004 American Sociological Association Presidential address: For public sociology, in: The British Journal of Sociology, 56, 2005, 2, 259-292; BURAWOY, Michael: Response: Public sociology: populist fad or path to renewal?, in: The British Journal of Sociology, 56, 2005, 2, 417-432.

31 KURCZEWSKA, 1979.

32 MUCHA, Janusz: Sociology in Central and Eastern Europe or East European Sociology: Historical and Present, in: Slovak Sociological Review, 41, 2009, 6, 507-524. 
they also set a powerful example for others regarding sociological work and publication practice, i.e. managing of sociological journals (approaching authors for contributions and their selection), influence on book production within sociological editions, translations and suchlike. Although it is difficult to reconstruct this indirect impact, it should be considered as it could be rather important.

At the same time we should not overlook intrinsic differences and tensions of the two national discourses. If we limit ourselves to the analysis of the journals, this tension resulting from the existence and character of controversies was greater in the Czech environment, where both the journals belonged to the antagonistically posed sociological schools. Taking into account the detailed analysis of similarities and differences between the two schools $^{33}$ that identified normativity for both of them, Burawoy's typology allows us to see that the dispute over engaged sociology in the Czech discourse was not a dispute over normativity in itself, but the character of normativity in fact. Whereas the circle of authors contributing to Sociologická revue de facto merged public and policy sociology, those connected with the competitive journal (the controversies were entered into by the younger representatives of the second generation, some of whom had spent some time studying at American universities) condemned the morality of 'obsolete' public sociology and championed the western instrumental concept of scientifically based social policy and social work (let us not forget that the name of their journal was Sociální problémy [Social Problems]).

One more observation regarding the problem of the nation should be added. Although it was only one of the many topics discussed in the Czech journals and it was marginal in the Polish ones, it seems to have been a crucial one in the period of non-institutionalized sociology at the end of the $19^{\text {th }}$ and beginning of the $20^{\text {th }}$ centuries. This is shown by the studies on the history of beginnings of Polish, ${ }^{34} \mathrm{Czech}^{35}$ and Slovak ${ }^{36}$ sociology. The relatively diminished interest in the topic was due to the development of professional sociology as conceived of by Burawoy, which was enabled by the institutional development of the science. The institutionalization of sociology itself was made possible by the established structures of a nation-state, whose formation had been supported, in a discursive manner, by sociology in its non-institutionalized form.

\section{Conclusion}

Our research focused on how the nation and the nation state shaped the first sociological journals in interwar Poland and Czechoslovakia. The research confirmed and specified the essential role of the nation state in the shaping of the institutional and to a great extent also the discursive character of the science. The leading figures of the Czech interwar sociology, specifically those of the editorial circles of sociological journals, had a closer connection with the political elites of the nation state between the wars as compared

33 See JANÁK, Dušan: Brněnská versus pražská sociologická škola: mýtus a skutečnost, in: Sociologický časopis, 49, 2013, 3, 577-602.

34 KURCZEWSKA, 1979; KURCZEWSKA, 2002; MUCHA, 2009, 516-518.

35 KILIAS, Jaroslaw: Naród a idea narodowa: nacjonalizm T. G. Masaryka, Warszawa 1998; KILIAS, 2000.

36 KLOBUCKÝ, 2006. 
with Poland. This may have been an advantage in the interwar period, but turned out to be a definite disadvantage in postwar development, after the change of the political regime. While the Polish journals survived not only the Second World War, but also the communist fight against the "bourgeois pseudo-science" that followed, the Czech journals never recovered from this attack. The Polish journals had tentative beginnings, but their continuity was maintained. Meanwhile, the promising start of the Czech periodicals was definitively broken with the onset of communism; this is reflected in the more radical discontinuity in the development of Czech sociology from then on, as compared to a certain degree of consistency retained in Poland. It also reflects the different character of the two political regimes. The weak connection with nation-state political elites made it easier for Polish sociology to survive and retain the institutional continuity of the discipline in the form of journals across different political regimes. The stronger connection with politics probably contributed to the relatively satisfactory status of the discipline, including journals in interwar Czechoslovakia, but also to its dramatic fall and serious discontinuities brought about not only at the institutional level.

It seems that the involvement in politics also affected to some extent the discursive level of sociology. One of the most significant differences between the Czech and the Polish journals involved the small amount of attention devoted to the theme of the nation in Polish journals and, in contrast, its extensive representation in Czech journals, dominated by its discussion in the politically relevant context (antifascism, Czech-Slovak relationships, the role of sociology in the national revival). The small proportion of articles on the subject of nation in Polish journals was likely related to its being worn out and at the same time, a political issue of the period. The theme remained popular among nationally oriented historians, even as sociologists tended to be in opposition to Dmowski's nationalist politics. From the viewpoint of typology of the sociological work division by M. Burawoy, a stronger position of public sociology as established at the beginning of the century still predominated in the Czech discourse, while in the Polish discourse it made more easily way for professional and policy sociology.

\section{References}

Sociologická revue 1930-1940.

Sociální problémy 1931-1938/1939.

Przegląd Socjologiczny 1930-1938.

Roczniki Socjologii Wsi 1936-1938.

BELL, Philip: Content Analysis of Visual Images, in: Handbook of visual analysis, LEEUWEN, Theo van - JEWITT, Carey (eds.), London - Thousand Oaks - New Delhi 2001, 10-34.

BURAWOY, Michael et al.: Public Sociologies: A Symposium from Boston College, in: Social Problems, 51, 2004, 1, 103-130.

BURAWOY, Michael: American Sociological Association Presidential address: For public sociology, in: The British Journal of Sociology, 56, 2005, 2, 259-292.

BURAWOY, Michael: Response: Public sociology: populist fad or path to renewal?, in: The British Journal of Sociology, 56, 2005, 2, 417-432. 
CHAŁASIŃSKI, Józef: Antagonizm polsko-niemiecki w fabrycznej osadzie "Kopalnia" na Górnym Śląsku, in: Przegląd Socjologiczny, 3, 1935, 1-2, 146-278.

CHAŁASIŃSKI, Józef: Trzydzieści lat socjologii polskiej, in: Przegląd Socjologiczny, vol. X, 1948, 1-57.

FISCHER, Josef, L.: "Na křižovatce", in: Sociologická revue, 9, 1938, (1-2), 260-264.

JANÁK, Dušan: Brněnská versus pražská sociologická škola: mýtus a skutečnost, in: Sociologický časopis, 49, 2013, 3, 577-602.

JANÁK, Dušan: Štefánek Anton, in: Slovník českých sociologů, NEŠPOR, Zdeněk R. a kol., Prague 2013, 398-400.

KÄSLER, Dirk: Soziologische Abenteuer: Earle Edward Eubank besucht eurupäische Soziologen im Sommer 1934, Opladen 1985.

KILIAS, Jaroslaw: Naród a idea narodowa: nacjonalizm T. G. Masaryka, Warszawa 1998.

KILIAS, Jaroslaw: Narodowość jako problem naukowy. Naród w socjologii czeskiej okresu międzywojennego, Warszawa 2000.

KILIAS, Jaroslaw: An older Brother: Polish and Czechoslovak Sociology in the 1960s, 2015. Unprinted paper.

KLOBUCKÝ, Robert: Hlasistické hnutie: národ a sociológia. Začiatky sociologického myslenia na Slovensku, Bratislava 2006.

KOSIĆ, Mirko: Stav sociologického studia u Jihoslovanů, in: Sociologická revue, 2, 1931, 3, 334-339.

KRAŚKO, Nina: Instytucjonalizacja socjologii w Polsce 1920-1970, Warszawa 1996.

KRIPPENDORF, Klaus: Testing the Reliability of Content analyzing Data: What is Involved and Why, in: The Content Analysis Reader, KRIPPENDORF, Klaus - BOCK, Mary Angela (eds.), Los Angeles - London - New Delhi - Singapore 2009, 350-357.

KUBICZEK, Franciszek: Historia Polski v liczbach. Zeszyt 4 - oświata, nauka, kultura, Warszawa 1992.

KUKLO, Cezary - ŁUKASIEWICZ, Juliusz - LESZCZYŃSKA, Cecylia: Historia Polski v lizcbach / History of Poland in Numbers, Warszawa 2014.

KURCZEWSKA, Joanna: Naród w socjologii i ideologii polskiej, Warszawa 1979.

KURCZEWSKA, Joanna: Dusza społeczeństwa. Naród w polskiej myśli socjologicznej, Warszawa 2002.

MORAWSKI, Wojciech: Władysław Grabski, polityk, mąź stanu, reformator, Warszawa 2004.

MUCHA, Janusz: Sociology in Central and Eastern Europe or East European Sociology: Historical and Present, in: Slovak Sociological Review, 41, 2009, 6, 507-524.

NEŠPOR, Zdeněk R.: Před 3/4 stoletím... Kvantifikovaný esej o časopisecké produkci české sociologie před nástupem marxismu a dnes, in: Sociologický časopis, 43, 2007, 2, 397422.

NEŠPOR, Zdeněk R.: Chalupný Emanuel, in: Slovník českých sociologů, NEŠPOR, Zdeněk R. a kol., Prague 2013, 126-136.

NEŠPOR, Zdeněk R.: Machotka Otakar, in: Slovník českých sociologů, NEŠPOR, Zdeněk R. a kol., Prague 2013, 222-229.

PAVLINCOVÁ, Helena: Chalupný a Brno, in: Emanuel Chalupný, česká kultura, česká sociologie a Tábor, ZUMR, Josef (ed.), Prague 1999, 23-31. 
PETRUSEK, Miroslav: Fischer Josef Ludvík, in: Slovník českých sociologů, NEŠPOR, Zdeněk R. a kol., Prague 2013, 72-83.

RIFFE, Daniel - LACY, Stephen - FICO, Frederick G.: Analyzing Media Messages. Using Quantitative Content Analyzes in Research, Mahwah - New Jersey - London 2005.

SCOTT, William A.: Scott's $\pi(\mathrm{Pi})$ : Reliability for Nominal Scale Coding, in: The Content Analysis Reader, KRIPPENDORF, Klaus - BOCK, Mary Angela (eds.), Los Angeles - London - New Delhi - Singapore 2009, 347-349.

SCHERER, Helmut: Úvod do obsahové analýzy, in: Analýza obsahu mediálních sdělení, SCHULZ, Winfried - HAGEN, Lutz - SCHERER, Helmut - REIFOVÁ, Irena - KONČELÍK, Jakub (eds.), Prague 1998, 29-53.

SEDLÁK, Jiř́: Inocenc Arnošt Bláha, Brno 1995.

SILVERMAN, David: Doing Qualitative Research. A Practical Handbook, London - Thousand Oaks - New Delhi 2000.

Statistická ročenka republiky Československé, Prague 1934.

ŠAPOVAL, Mykyta: Soudobá ukrajinská sociologická myšlenka a práce, in: Sociologická revue, 2, 1931, 2, 195-202.

ŠAPOVAL, Mykyta: Soudobá ukrajinská sociologická myšlenka a práce, in: Sociologická revue, 2, 1931, 4, 49-55.

ŠTEFÁNEK, Anton: Príspevok ku československému bilinguizmu, in: Sociologická revue, 2, 1931, 1, 20-29.

ŠTEFÁNEK, Anton: Novoslováci, in: Sociologická revue, 4, 1935, 3-4, 272-277.

VORÁČEK, Emil: Emanuel Chalupný, problémy rozvoje sociologie v Československu 20. let a vznik Masarykovy sociologické společnosti, in: Emanuel Chalupný, česká kultura, česká sociologie a Tábor, ZUMR, Josef (ed.), Prague 1999, 107-132.

WINCŁAWSKI, Włodzimierz: Słownik biograficzny socjologii polskiej, Toruń 2001.

\section{Author}

PhDr. Dušan Janák, Ph.D.

Centrum empirických výzkumů, Fakulta veřejných politik, Slezská univerzita v Opavě Centre of Empirical Research, Faculty of Public Policies, Silesian University in Opava Bezručovo nám. 885/14, 74601 Opava, The Czech Republic janak@fvp.slu.cz 